\title{
Role of Hydrogen Sulfide and Polysulfides in the Regulation of Lipolysis in the Adipose Tissue: Possible Implications for the Pathogenesis of Metabolic Syndrome
}

\author{
Jerzy Bełtowski ${ }^{1, *}$ and Krzysztof Wiórkowski ${ }^{2}$ \\ 1 Department of Pathophysiology, Medical University of Lublin, 20-090 Lublin, Poland \\ 2 Luxmed Lublin Medical Center-Primary Care Unit, 20-080 Lublin, Poland; kwiorkowski@gmail.com \\ * Correspondence: jerzy.beltowski@umlub.pl; Tel.: +48-814486500
}

check for

updates

Citation: Bełtowski, J.; Wiórkowski,

K. Role of Hydrogen Sulfide and

Polysulfides in the Regulation of

Lipolysis in the Adipose Tissue:

Possible Implications for the

Pathogenesis of Metabolic Syndrome.

Int. J. Mol. Sci. 2022, 23, 1346.

https://doi.org/10.3390/

ijms23031346

Academic Editors: Marcin

Magierowski and Binghe Wang

Received: 30 December 2021

Accepted: 24 January 2022

Published: 25 January 2022

Publisher's Note: MDPI stays neutral with regard to jurisdictional claims in published maps and institutional affiliations.

Copyright: (c) 2022 by the authors. Licensee MDPI, Basel, Switzerland. This article is an open access article distributed under the terms and conditions of the Creative Commons Attribution (CC BY) license (https:// creativecommons.org/licenses/by/ $4.0 /)$.

\begin{abstract}
Hydrogen sulfide $\left(\mathrm{H}_{2} \mathrm{~S}\right)$ and inorganic polysulfides are important signaling molecules; however, little is known about their role in the adipose tissue. We examined the effect of $\mathrm{H}_{2} \mathrm{~S}$ and polysulfides on adipose tissue lipolysis. $\mathrm{H}_{2} \mathrm{~S}$ and polysulfide production by mesenteric adipose tissue explants in rats was measured. The effect of $\mathrm{Na}_{2} \mathrm{~S}$ and $\mathrm{Na}_{2} \mathrm{~S}_{4}$, the $\mathrm{H}_{2} \mathrm{~S}$ and polysulfide donors, respectively, on lipolysis markers, plasma non-esterified fatty acids (NEFA) and glycerol, was examined. $\mathrm{Na}_{2} \mathrm{~S}$ but not $\mathrm{Na}_{2} \mathrm{~S}_{4}$ increased plasma NEFA and glycerol in a time- and dose-dependent manner. $\mathrm{Na}_{2} \mathrm{~S}$ increased cyclic AMP but not cyclic GMP concentration in the adipose tissue. The effect of $\mathrm{Na}_{2} \mathrm{~S}$ on NEFA and glycerol was abolished by the specific inhibitor of protein kinase A, KT5720. The effect of $\mathrm{Na}_{2} \mathrm{~S}$ on lipolysis was not abolished by propranolol, suggesting no involvement of $\beta$-adrenergic receptors. In addition, $\mathrm{Na}_{2} \mathrm{~S}$ had no effect on phosphodiesterase activity in the adipose tissue. Obesity induced by feeding rats a highly palatable diet for 1 month was associated with increased plasma NEFA and glycerol concentrations, as well as greater $\mathrm{H}_{2} \mathrm{~S}$ production in the adipose tissue. In conclusion, $\mathrm{H}_{2} \mathrm{~S}$ stimulates lipolysis and may contribute to the enhanced lipolysis associated with obesity.
\end{abstract}

Keywords: adipose tissue; lipolysis; hydrogen sulfide; polysulfides; obesity

\section{Introduction}

Adipose tissue is one of the most abundant tissues in human body. For a long time considered only as a passive site of energy storage, adipose tissue is now recognized as a very active metabolic and endocrine organ. Fatty acids liberated from triglycerides stored in the adipose tissue represent an important source of energy for many organs. Adipose tissue is one of the target tissues for insulin and, as such, is involved in the regulation of systemic insulin sensitivity and resistance. In addition, adipose tissue produces many hormones referred to as adipokines, such as leptin, resistin, visfatin, adiponectin, etc. [1-4]. Specific adipose tissue depots also have special functions. For example, perivascular adipose tissue (PVAT), which surrounds the blood vessels, produces vasodilating and anti-inflammatory mediators, which have an important role in maintaining vascular homeostasis; however, obesity is associated with PVAT dysfunction due to its inflammation and local oxidative stress [5,6]. Unlike white adipose tissue, brown adipose tissue (BAT) contains many small lipid droplets and many mitochondria, and is characterized by intensive fatty acid oxidation through uncoupled mitochondrial respiration with little ATP production and a large amount of energy dissipated as heat, making it important in thermogenesis. Interestingly, in addition to fatty acids, BAT can oxidize other metabolites such as glucose, lactate, succinate and branch-chain amino acids [7]. BAT also secretes mediators which improve the metabolism of remote tissues and are referred to as BATokines [8]. Research interest in adipose tissue has expanded due to increasing prevalence of obesity and metabolic syndrome, which is a cluster of obesity-associated abnormalities such as dyslipidemia, 
impaired glucose tolerance/Type 2 diabetes, arterial hypertension, chronic prothrombotic and pro-inflammatory states, all of which contribute to the development of atherosclerosis, ischemic heart disease, heart failure, nephropathy, neuroinflammation and certain cancers $[1,9,10]$.

Lipolysis is the principal metabolic process in the adipose tissue. In adipocytes, triglycerides are hydrolyzed to glycerol and fatty acids by sequential action of adipose triglyceride lipase (ATGL), hormone-sensitive lipase (HSL) and monoglyceride lipase (MGL). Glycerol is then released to the extracellular space, and fatty acids are either released or re-esterified to triglycerides inside the adipose tissue. Obesity and metabolic syndrome are characterized by enhanced adipose tissue lipolysis and an increased non-esterified fatty acid (NEFA) concentration, which contributes to insulin resistance, dyslipidemia, endothelial dysfunction and lipotoxicity [11-14]. Lipolysis is a highly regulated process. The main target of regulation is HSL, which is activated through phosphorylation by cAMP-stimulated protein kinase A (PKA). The main activators of this pathway are catecholamines binding to $\beta_{2}$ and/or $\beta_{3}$-adrenergic receptors. In addition, HSL may be phosphorylated by cGMPactivated protein kinase $\mathrm{G}(\mathrm{PKG})$ in response to factors such as nitric oxide and natriuretic peptides. The main inhibitor of lipolysis is insulin, which activates phosphodiesterase and decreases cAMP concentrations [12,14].

Apart from peptide hormones (adipokines), gasotransmitters, including $\mathrm{NO}, \mathrm{CO}$ and $\mathrm{H}_{2} \mathrm{~S}$, are also produced in the adipose tissue [15]. The $\mathrm{H}_{2} \mathrm{~S}$ produced by perivascular adipose tissue is involved in the regulation of vascular tone [16]. In addition, $\mathrm{H}_{2} \mathrm{~S}$ is involved in the regulation of adipogenesis [17], insulin-stimulated glucose uptake [18], adipokine production [19] and adipose tissue inflammation [20]. However, little is known about the role of $\mathrm{H}_{2} \mathrm{~S}$ in the regulation of lipolysis.

Recent studies have suggested that, apart from $\mathrm{H}_{2} \mathrm{~S}$, inorganic polysulfides $\left(\mathrm{H}_{2} \mathrm{~S}_{\mathrm{n}}\right.$, $\mathrm{n}=2-8$ ) are also important signaling molecules. $\mathrm{H}_{2} \mathrm{~S}_{n}$ polysulfides are produced by partial oxidation of $\mathrm{H}_{2} \mathrm{~S}$ or its interaction with $\mathrm{NO}$, or are directly synthesized enzymatically by 3-mercaptopyruvate sulfurtransferase (MST) [21]. In some experimental systems, polysulfides are much more potent than $\mathrm{H}_{2} \mathrm{~S}$. Indeed, persulfidation of protein cysteine residues, believed to be the main signaling mechanism of $\mathrm{H}_{2} \mathrm{~S}$, can be accounted for by $\mathrm{H}_{2} \mathrm{~S}_{n}$ rather than $\mathrm{H}_{2} \mathrm{~S}$ itself [21-23]. It is unclear if polysulfides are produced in the adipose tissue and, if so, what their function is. In the present study, we examined the role of $\mathrm{H}_{2} \mathrm{~S}$ and polysulfides in the regulation of adipose tissue lipolysis.

\section{Results}

\section{1. $\mathrm{H}_{2} \mathrm{~S}$ and Polysulfide Production by Adipose Tissue}

$\mathrm{H}_{2} \mathrm{~S}$ and polysulfide production was measured by mesenteric adipose tissue explants ex vivo. Very small amounts of $\mathrm{H}_{2} \mathrm{~S}$ and $\mathrm{H}_{2} \mathrm{~S}_{\mathrm{n}}$ were produced by adipose tissue in the absence of L-cysteine (L-Cys) and pyridoxal $5^{\prime}$-phosphate (PLP), which are the substrate and cofactor, respectively, of cystathionine $\beta$-synthase (CBS) and cystathionine $\gamma$-lyase (CSE). Adipose tissue incubated in the presence of L-Cys and PLP produced more polysulfides than $\mathrm{H}_{2} \mathrm{~S}$ (Figure 1). A CSE inhibitor, propargylglycine (PAG), markedly reduced $\mathrm{H}_{2} \mathrm{~S}$ but had no effect on $\mathrm{H}_{2} \mathrm{~S}_{\mathrm{n}}$ production. Adipose tissue incubated in the presence of the MST substrate 3-mercapropyruvate (3-MP), but without L-Cys and PLP, produced less $\mathrm{H}_{2} \mathrm{~S}$ than in the presence of L-Cys and PLP. However, $\mathrm{H}_{2} \mathrm{~S}_{n}$ production in the presence of 3-MP was similar to that observed in the presence of L-Cys and PLP. Inhibitors of MST, L-aspartate and phenylpyruvate, reduced $\mathrm{H}_{2} \mathrm{~S}$ and $\mathrm{H}_{2} \mathrm{~S}_{\mathrm{n}}$ production in the presence of 3-MP but had no effect on $\mathrm{H}_{2} \mathrm{~S}$ production in the presence of L-Cys and PLP. These results suggest that $\mathrm{H}_{2} \mathrm{~S}$ is produced in the adipose tissue mainly by CSE and, to a lesser extent, by MST, whereas the latter enzyme is responsible for polysulfide production (Figure 1). 

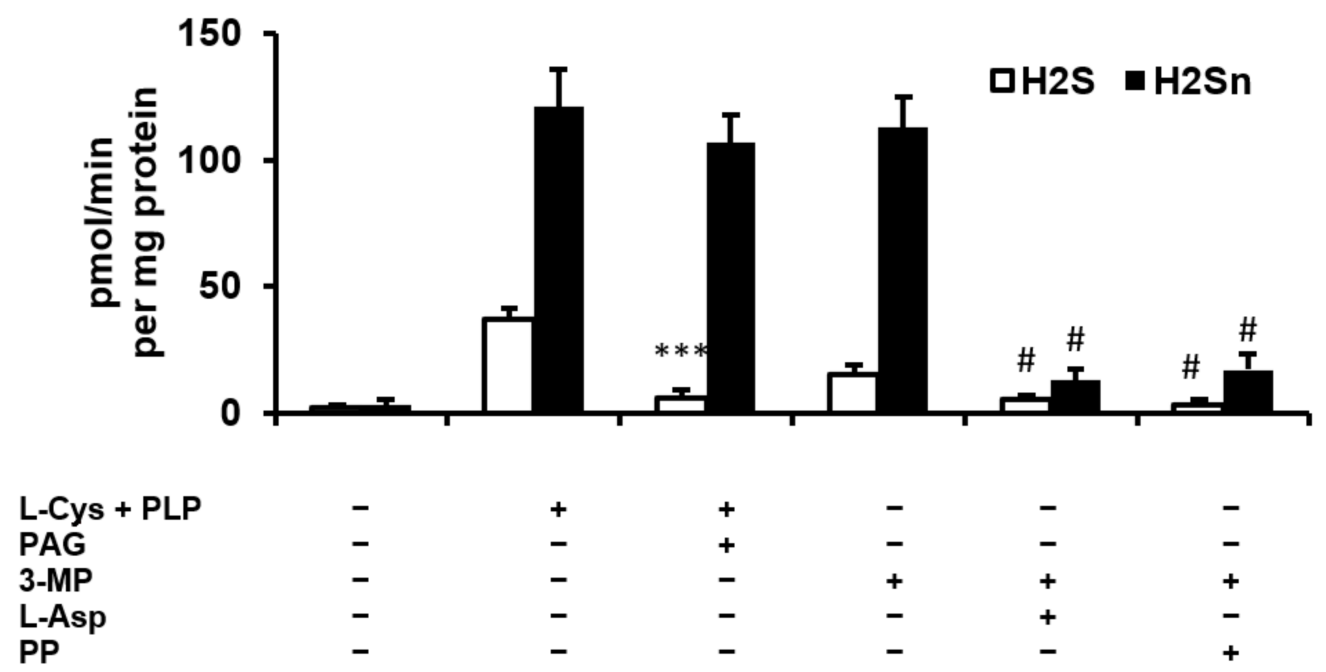

$\begin{array}{ll}- & \\ - & \\ - & \end{array}$

$\begin{array}{ll}+ & + \\ - & + \\ - & - \\ - & -\end{array}$

Figure 1. Hydrogen sulfide $\left(\mathrm{H}_{2} \mathrm{~S}\right)$ and polysulfide $\left(\mathrm{H}_{2} \mathrm{~S}_{\mathrm{n}}\right)$ production by adipose tissue slices ex vivo in the presence or absence of L-cysteine (L-Cys, $1 \mathrm{mM}$ ), pyridoxal 5'-phosphate (PLP, $1 \mathrm{mM}$ ), propargylglycine (PAG, $1 \mathrm{mM}$ ), 3-mercaptopyruvate (3-MP, $5 \mathrm{mM}$ ), L-aspartate (L-Asp, $3 \mathrm{mM}$ ) and phenylpyruvate $(\mathrm{PP}, 10 \mathrm{mM}) .{ }^{* * *} p<0.001$ vs. sample incubated in the presence of L-Cys + PLP, \# $p<0.001$ vs. sample incubated in the presence of 3-MP.

\subsection{Effect of $\mathrm{Na}_{2} \mathrm{~S}$ and $\mathrm{Na}_{2} \mathrm{~S}_{4}$ on Non-Esterified Fatty Acids and Glycerol Concentration}

$\mathrm{Na}_{2} \mathrm{~S}$ injected at a dose of $100 \mu \mathrm{mol} / \mathrm{kg}$ increased plasma NEFA concentrations in a time-dependent manner. The maximal NEFA level was observed 15 min after injection (Figure 2a). In contrast, $\mathrm{Na}_{2} \mathrm{~S}_{4}$ had no significant effect on plasma NEFA. Consequently, the area under the curve of plasma NEFA between 0 and $60 \mathrm{~min}$ after $\mathrm{Na}_{2} \mathrm{~S}$ injection was much higher than in control animals receiving $0.9 \% \mathrm{NaCl}$ (Figure $2 \mathrm{~b}$ ).

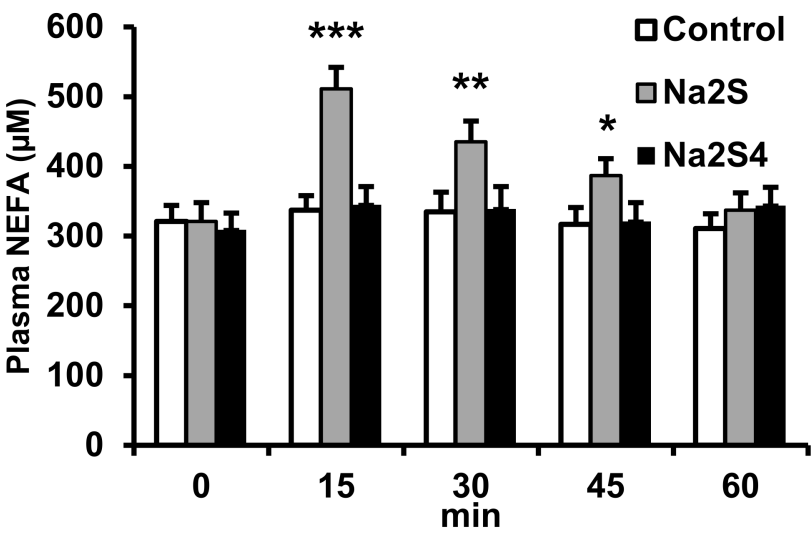

(a)



(b)

Figure 2. Effect of $\mathrm{Na}_{2} \mathrm{~S}$ and $\mathrm{Na}_{2} \mathrm{~S}_{4}$ on plasma non-esterified fatty acids (NEFA). Plasma NEFA concentrations at different time points after injection of $0.9 \% \mathrm{NaCl}$ (control), $\mathrm{Na}_{2} \mathrm{~S}(100 \mu \mathrm{mol} / \mathrm{kg}$ ) or $\mathrm{Na}_{2} \mathrm{~S}_{4}(100 \mu \mathrm{mol} / \mathrm{kg})(\mathbf{a})$. The area under the curve (AUC) of plasma NEFA concentration was calculated for 0-60 min period after $\mathrm{NaC}, \mathrm{Na}_{2} \mathrm{~S}$ or $\mathrm{Na}_{2} \mathrm{~S}_{4}$ administration (b). ${ }^{*} p<0.05,{ }^{* *} p<0.01$, *** $p<0.001$ vs. baseline level in the control group.

Similarly, $\mathrm{Na}_{2} \mathrm{~S}$ but not $\mathrm{Na}_{2} \mathrm{~S}_{4}$ increased plasma glycerol concentrations in a timedependent manner (Figure 3). The effect of $\mathrm{Na}_{2} \mathrm{~S}_{2}$ on plasma NEFA and glycerol at $15 \mathrm{~min}$ after injection was dose-dependent (Figure 4). The minimal dose of $\mathrm{Na}_{2} \mathrm{~S}$ that induced significant increases in plasma NEFA and glycerol was $10 \mu \mathrm{mol} / \mathrm{kg}$. Taken together, the results suggest that $\mathrm{H}_{2} \mathrm{~S}$, but not polysulfides, stimulates lipolysis in the adipose tissue. 


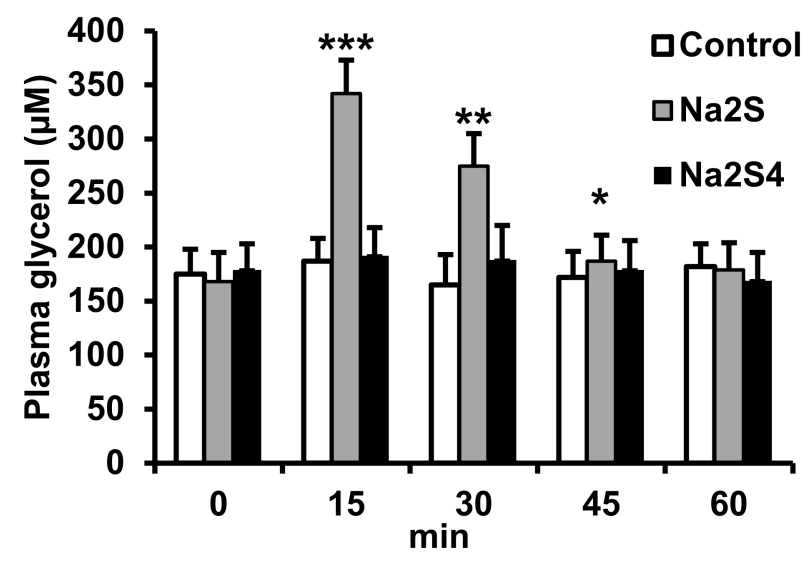

(a)



(b)

Figure 3. Effect of $\mathrm{Na}_{2} \mathrm{~S}$ and $\mathrm{Na}_{2} \mathrm{~S}_{4}$ on plasma glycerol. Plasma glycerol concentrations were measured at different time points after the injection of $0.9 \% \mathrm{NaCl}$ (control), $\mathrm{Na}_{2} \mathrm{~S}(100 \mu \mathrm{mol} / \mathrm{kg})$ or $\mathrm{Na}_{2} \mathrm{~S}_{4}(100 \mu \mathrm{mol} / \mathrm{kg})(\mathbf{a})$. The area under the curve (AUC) of plasma glycerol concentration was calculated for a 0-60 min period after $\mathrm{NaC}, \mathrm{Na}_{2} \mathrm{~S}$ or $\mathrm{Na}_{2} \mathrm{~S}_{4}$ administration $(\mathbf{b})$. ${ }^{*} p<0.05,{ }^{* *} p<0.01$, *** $p<0.001$ vs baseline level in the control group.

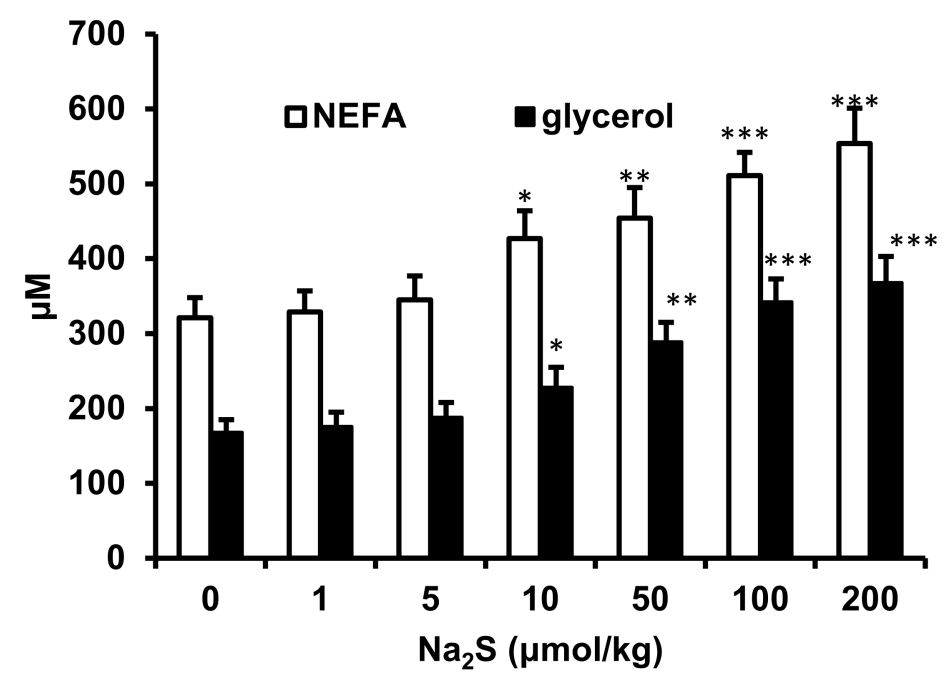

Figure 4. Dose-dependent effect of $\mathrm{Na}_{2} \mathrm{~S}$ on plasma NEFA and glycerol concentrations measured 15 min after injection. ${ }^{*} p<0.05,{ }^{* *} p<0.01{ }^{* * *} p<0.001$ vs. values before $\mathrm{Na}_{2} \mathrm{~S}$ administration.

2.3. Role of Cyclic Nucleotides and Cyclic Nucleotide-Dependent Protein Kinases in the Regulation of Lipolysis by $\mathrm{Na}_{2} \mathrm{~S}$

Cyclic AMP (cAMP)-dependent protein kinase A (PKA) and cGMP-dependent protein kinase $\mathrm{G}$ (PKG) play an important role in the regulation of lipolysis by phosphorylating hormone-sensitive lipase in adipocytes, To examine if cyclic nucleotides and the respective kinases are involved in $\mathrm{Na}_{2} \mathrm{~S}$-stimulated lipolysis, we measured cAMP and cGMP concentrations in the adipose tissue, and examined the effect of protein kinase inhibitors on the lipolytic response to $\mathrm{Na}_{2} \mathrm{~S} . \mathrm{Na}_{2} \mathrm{~S}$ increased cAMP but not cGMP in adipose tissue (Figure 5a), whereas $\mathrm{Na}_{2} \mathrm{~S}_{4}$ had no effect (data not shown). Neither the PKA nor the PKG inhibitor (KT5720 and KT5823, respectively) had a significant effect on plasma NEFA and glycerol if administered to rats not receiving $\mathrm{Na}_{2} \mathrm{~S}$ (not shown). However, KT5720 but not KT5823 abolished the $\mathrm{Na}_{2} \mathrm{~S}$-induced increase in plasma NEFA and glycerol (Figure 5b). These data suggest that the cAMP-PKA pathway but not the cGMP-PKG pathway is involved in the stimulation of lipolysis by $\mathrm{H}_{2} \mathrm{~S}$. 


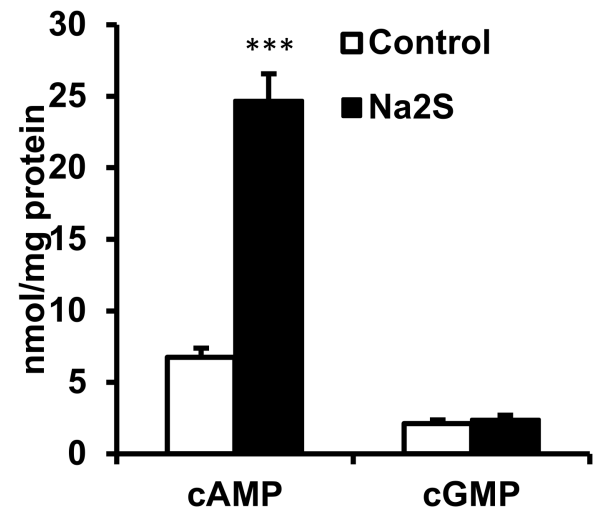

(a)

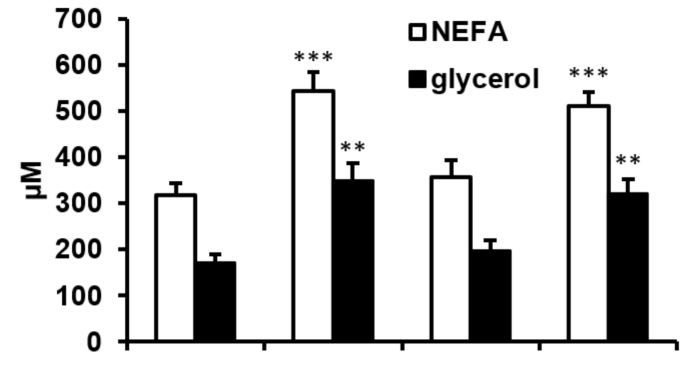

$\begin{array}{lllll}\mathrm{KT5720} & - & - & + & - \\ \mathrm{KY}_{\mathrm{Na}} \mathrm{S} & - & - & - & +\end{array}$

(b)

Figure 5. Role of cyclic nucleotides and cyclic nucleotide-dependent protein kinases in the regulation of lipolysis. (a) Effect of $\mathrm{Na}_{2} \mathrm{~S}(100 \mu \mathrm{mol} / \mathrm{kg})$ on cAMP and cGMP concentrations in the adipose tissue. (b): Effect of the PKA and PKG inhibitors KT5720 and KT5823, respectively, (each administered at $1 \mu \mathrm{mol} / \mathrm{kg}$ ) on NEFA and glycerol concentrations in animals injected with $100 \mu \mathrm{mol} / \mathrm{kg} \mathrm{Na}_{2} \mathrm{~S}$. ${ }^{* *} p<0.01,{ }^{* * *} p<0.001$ vs. rats not receiving $\mathrm{Na}_{2} \mathrm{~S}$.

\subsection{Role of the Adrenergic System in the Regulation of Lipolysis by $\mathrm{Na}_{2} \mathrm{~S}$}

Norepinephrine released by sympathetic endings, and epinephrine and norepinephrine secreted by the adrenal medulla and circulating in the blood stimulate lipolysis by binding to $\beta$-adrenergic receptors and activating the cAMP-PKA pathway. To examine if $\beta$-adrenergic receptors are involved in the stimulation of lipolysis by $\mathrm{H}_{2} \mathrm{~S}$, we performed additional experiments using a $\beta$-adrenergic agonist, isoproterenol, and a $\beta$-adrenergic antagonist, propranolol. Propranolol administered to the rats not receiving $\mathrm{Na}_{2} \mathrm{~S}$ had no effect on plasma NEFA and glycerol concentrations (not shown). As expected, isoproterenol administered at $1 \mathrm{mg} / \mathrm{kg}$ potently stimulated lipolysis, as evidenced by the marked increase in plasma NEFA and glycerol (Figure 6). The effect of isoproterenol was prevented by earlier administration of propranolol. However, propranolol had no effect on the $\mathrm{Na}_{2} \mathrm{~S}$-induced increase in NEFA and glycerol (Figure 6).

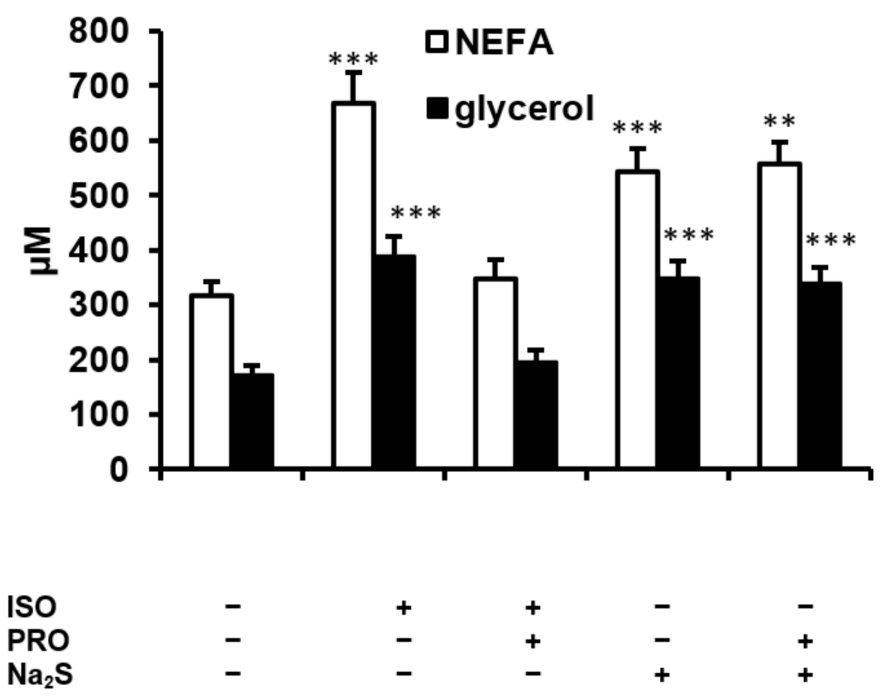

Figure 6. Effect of the $\beta$-adrenergic agonist isoproterenol (ISO) and the $\beta$-adrenergic antagonist propranolol (PRO) on plasma NEFA and glycerol concentrations in rats treated with or without $\mathrm{Na}_{2} \mathrm{~S}(100 \mu \mathrm{mol} / \mathrm{kg}) .{ }^{* *} p<0.01,{ }^{* * *} p<0.001$ vs. control group not receiving $\mathrm{Na}_{2} \mathrm{~S}$, isoproterenol or propranolol. 


\subsection{Effect of $\mathrm{Na}_{2} \mathrm{~S}$ on cAMP-Hydrolyzing Phosphodiesterase Activity in Adipose Tissue}

The intracellular cAMP concentration is dependent not only on its synthesis by adenylyl cyclase but also by its degradation by phosphodiesterases (PDE). Because we have demonstrated that $\mathrm{Na}_{2} \mathrm{~S}$ stimulates the cAMP-PKA pathway but $\beta$-adrenergic receptors, the main adenylyl cyclase-activating receptors in the adipose tissue, are not involved, we hypothesized that $\mathrm{Na}_{2} \mathrm{~S}$ could increase cAMP by inhibiting PDE. However, $\mathrm{Na}_{2} \mathrm{~S}(100 \mu \mathrm{mol} / \mathrm{kg})$ had no effect on PDE activity in the adipose tissue (control group: $78 \pm 16 \mathrm{pmol} / \mathrm{min}$ per $\mathrm{mg}$ protein; $\mathrm{Na}_{2} \mathrm{~S}$-treated group: $86 \pm 14 \mathrm{pmol} / \mathrm{min}$ per $\mathrm{mg}$ protein)

\subsection{Effect of Obesity on Metabolic Parameters, $\mathrm{H}_{2} \mathrm{~S}$ and Polysulfide Production in Adipose Tissue}

Feeding rats with a high-calorie diet for 1 month resulted in a significant increase in body weight; however, plasma lipids, insulin and glucose concentrations did not differ from those of the control group (Table 1). However, plasma NEFA and glycerol levels were significantly higher in obese rats. The adipose tissue of obese rats produced more $\mathrm{H}_{2} \mathrm{~S}$ than that from lean animals. Polysulfide production by adipose tissue explants isolated from obese rats tended to be lower than in lean animals but the difference was not significant (Table 1).

Table 1. Effect of obesity on metabolic parameters, $\mathrm{H}_{2} \mathrm{~S}$ and polysulfide production in adipose tissue.

\begin{tabular}{ccc}
\hline & Control & Obese \\
\hline Body weight $(\mathrm{g})$ & $221 \pm 16$ & $268 \pm 18^{* *}$ \\
Triglycerides $(\mathrm{mM})$ & $0.81 \pm 0.05$ & $0.88 \pm 0.08$ \\
Total cholesterol $(\mathrm{mM})$ & $2.08 \pm 0.23$ & $2.15 \pm 0.27$ \\
NEFA $(\mu \mathrm{M})$ & $352 \pm 25$ & $714 \pm 46^{* * *}$ \\
Glycerol $(\mu \mathrm{M})$ & $172 \pm 15$ & $252 \pm 19^{* * *}$ \\
Insulin $(\mu \mathrm{U} / \mathrm{mL})$ & $21.3 \pm 2.5$ & $23.4 \pm 2.9$ \\
Glucose $(\mathrm{mM})$ & $4.22 \pm 0.51$ & $4.44 \pm 0.58$ \\
$\mathrm{H}_{2}$ S production (pmol/min per mg protein) & $32.7 \pm 3.5$ & $72.6 \pm 6.1^{* * *}$ \\
Polysulfide production (pmol/min per mg protein) & $116.4 \pm 26.7$ & $101.7 \pm 19.4$ \\
${\text { ** } p<0.01,{ }^{* * *} p<0.001 \text { vs. control group. }}$ &
\end{tabular}

\section{Discussion}

The main findings of this study are that: (1) both $\mathrm{H}_{2} \mathrm{~S}$ and polysulfides are produced in the adipose tissue, and, under physiological conditions, the amount of polysulfides is higher than that of $\mathrm{H}_{2} \mathrm{~S}$; (2) $\mathrm{H}_{2} \mathrm{~S}$ stimulates lipolysis in a cAMP-PKA-dependent but $\beta$-adrenergic receptor-independent manner; (3) obesity induced by a high-calorie diet increases $\mathrm{H}_{2} \mathrm{~S}$ but not $\mathrm{H}_{2} \mathrm{~S}_{\mathrm{n}}$ production in the adipose tissue.

In 2009, it was first demonstrated that $\mathrm{H}_{2} \mathrm{~S}$ is produced by various adipose tissue depots, including epidydimal, perirenal and brown adipose tissue in the rat, and that CSE is the main enzymatic source of this gasotransmitter [18]. Since that time, the expression of all $\mathrm{H}_{2} \mathrm{~S}$-synthesizing enzymes (CBS, CSE, MST) and $\mathrm{H}_{2} \mathrm{~S}$ production have been demonstrated in various adipose tissue depots in rodents and humans [15]. In addition, Cthe $\mathrm{SE}-\mathrm{H}_{2} \mathrm{~S}$ system is upregulated during adipogenesis and is involved in this process [24]. We confirmed that $\mathrm{H}_{2} \mathrm{~S}$ production in the adipose tissue is mainly accounted for by CSE, as evidenced by the marked inhibitory effect of $\mathrm{PAG}$, as well as much lower $\mathrm{H}_{2} \mathrm{~S}$ production in the presence of MST substrate than in the presence of the CSE substrate. On the other hand, MST appears to be the main source of polysulfides. Indeed, $\mathrm{H}_{2} \mathrm{~S}_{\mathrm{n}}$ production was poorly inhibited by PAG, was observed in the presence of 3-mercaptopyruvate and was markedly inhibited by MST inhibitors. These findings are consistent with recent findings suggesting that MST produces polysulfides or protein persulfides directly but to a much lesser extent $\mathrm{H}_{2} \mathrm{~S}$ itself, and that MST is the main source of $\mathrm{H}_{2} \mathrm{~S}_{\mathrm{n}}$ in the brain [25]. Polysulfides may also be synthesized during partial enzymatic or non-enzymatic oxidation of $\mathrm{H}_{2} \mathrm{~S}$ [21]; however, the divergent effects of CSE and MST substrates and inhibitors on $\mathrm{H}_{2} \mathrm{~S}$ 
and $\mathrm{H}_{2} \mathrm{~S}_{\mathrm{n}}$ suggest that both are produced independently in the adipose tissue and could have different physiological roles.

The role of $\mathrm{H}_{2} \mathrm{~S}$ in the regulation of adipose tissue lipolysis has been examined in few studies so far. Geng at al. [26] demonstrated that L-cysteine and the slow-releasing $\mathrm{H}_{2} \mathrm{~S}$ donor, GYY4137, inhibited baseline and isoproterenol-stimulated glycerol release by epidydimal adipose tissue in rats and reduced HSL phosphorylation, whereas propargylglycine had the opposite effect. In vivo, propargylglycine increased plasma glycerol concentration in mice fed normal chow, and tended, although not significantly, to increase glycerol in mice fed a high-fat diet, whereas GYY4137 reduced glycerol concentrations only in mice fed a high-fat diet. Ding et al. [27] demonstrated that NaHS reduces basal and isoproterenol-stimulated glycerol release by the epidydimal adipose tissue of mice fed a high-fat diet; however, the effect on adipose tissue collected from lean animals has not been examined. In addition, NaHS reduced HSL phosphorylation, which probably resulted from increased persulfidation of its regulator, perilipinm-1. On the other hand, the adipose tissue of CSE knockout mice exhibited greater glycerol release [27]. These results suggest that $\mathrm{H}_{2} \mathrm{~S}$ inhibits lipolysis, which is not consistent with the results of the present study. The reasons for this discrepancy are unclear but several possibilities should be considered. First, $\mathrm{H}_{2} \mathrm{~S}$ could regulate lipolysis in a species-dependent manner. Second, our study was performed in lean animals, whereas the study of Ding et al. [27] was in mice fed a high-fat diet. High-fat feeding increases the baseline lipolysis rate, and $\mathrm{H}_{2} \mathrm{~S}$ could have different effects on lipolysis in lean and obese animals. Third, the effect of $\mathrm{H}_{2} \mathrm{~S}$ on lipolysis could be different in in vitro/ex vivo studies using adipocytes or isolated adipose tissue [27] than in vivo, when endogenous neurohormonal systems regulating lipolysis are active. Finally, we used $\mathrm{Na}_{2} \mathrm{~S}$ as the $\mathrm{H}_{2} \mathrm{~S}$ donor, whereas Ding et al. [27] used NaHS and GYY4137. According to some studies [28], NaHS is more susceptible to oxidation than $\mathrm{Na}_{2} \mathrm{~S}$, and its solution could contain other more oxidized reactive sulfur species with potentially different effects. Although GYY4137 is considered a more physiologically relevant $\mathrm{H}_{2} \mathrm{~S}$ donor, as it releases gasotransmitters slowly and for a prolonged time [29,30], it has also some limitations. In particular, both GYY4137 and the products of its decomposition may have some $\mathrm{H}_{2} \mathrm{~S}$-independent effects [31,32]. In addition, in one study [33], it was demonstrated that GYY4137 does not release $\mathrm{H}_{2} \mathrm{~S}$ in rat plasma and, in contrast to $\mathrm{Na}_{2} \mathrm{~S}$, is ineffective in lowering blood pressure in the rat. Moreover, there is no polysulfide donor structurally related to GYY4137; therefore, we used $\mathrm{Na}_{2} \mathrm{~S}$ and $\mathrm{Na}_{2} \mathrm{~S}_{4}$ as the closely related donors. Interestingly, garlic extract, which contains natural organic $\mathrm{H}_{2} \mathrm{~S}$ donors, stimulated lipolysis in 3T3-L1 adipocytes [34]. These data indicate that various $\mathrm{H}_{2} \mathrm{~S}$ donors could have different effects on lipolysis.

The results of this study indicate that $\mathrm{H}_{2} \mathrm{~S}$ stimulates lipolysis in a cAMP-PKA dependent but $\beta$-adrenergic receptor independent manner. The mechanism through which $\mathrm{H}_{2} \mathrm{~S}$ increases cAMP in the adipose tissue remains to be established. In adipocytes, adenylyl cyclase is stimulated by the agonists of at least 10 other G-protein-coupled receptors in addition to $\beta$-adrenergic receptors [35]. Cai et al. [17] demonstrated that GYY4137 reduced whereas propargylglycine increased phosphodiesterase activity in 3T3-L1 adipocytes. However, we did not observe any effect of $\mathrm{Na}_{2} \mathrm{~S}$ on phosphodiesterase activity. Another possibility is direct stimulation of adenylyl cyclase by $\mathrm{H}_{2} \mathrm{~S}$; this effect has been observed in several non-adipose tissue systems [36].

The effect of obesity on the adipose tissue $\mathrm{H}_{2} \mathrm{~S}$ system is controversial. Both increases [18] and decreases [26,30,37,38] in the expression of CBS, CSE, MST and adipose tissue $\mathrm{H}_{2} \mathrm{~S}$ production have been observed, depending on type of diet, the duration of highcalorie feeding, the animal species and adipose tissue depots. Increased $\mathrm{H}_{2} \mathrm{~S}$ excretion in the exhaled air of obese children [39] and increased plasma $\mathrm{H}_{2} \mathrm{~S}$ in morbidly obese adults [40] have been reported. Interestingly, in an early study on this topic, Whiteman et al. [41] observed that plasma $\mathrm{H}_{2} \mathrm{~S}$ concentration was moderately reduced in overweight or obese patients without diabetes but markedly reduced in obese patients with Type 2 diabetes and insulin resistance. These results suggest that more advanced metabolic syndrome is 
associated with $\mathrm{H}_{2} \mathrm{~S}$ deficiency. Indeed, in studies in which reduced adipose tissue $\mathrm{H}_{2} \mathrm{~S}$ has been observed, a high-calorie diet was applied for a long time, leading to severe obesity, dyslipidemia, insulin resistance and/or Type 2 diabetes [26,37]. It should be noted that our model represented relatively mild obesity with no evidence of the metabolic abnormalities characteristic of metabolic syndrome because plasma insulin, glucose and lipid levels were within the normal range. However, plasma NEFA and glycerol concentrations were higher in obese than in control rats, which is consistent with increased adipose tissue lipolysis. Together with higher $\mathrm{H}_{2} \mathrm{~S}$ production in the adipose tissue, these findings suggest that $\mathrm{H}_{2} \mathrm{~S}$ could be involved in hyperlipolysis in the obese group. However, further studies are required to verify this hypothesis.

One of the important effects of insulin is to suppress lipolysis in the fasting state. Although fasting insulin concentrations were normal in obese rats in our study, suggesting intact insulin sensitivity, we cannot exclude that the antilipolytic effect of insulin in the adipose tissue was specifically impaired. However, this possibility seems unlikely because it is generally appreciated that the effect of insulin on glucose metabolism is impaired earlier during the development of insulin resistance, and that only severe insulin resistance or deficiency impair its effect on lipolysis. Nevertheless, the effect of insulin on adipose tissue should be studied directly in our model to address this issue.

Our study has several limitations. First, the method we used could not discriminate between various polysulfides, and we used only one polysulfide donor $\left(\mathrm{Na}_{2} \mathrm{~S}_{4}\right)$. Studies in other systems have indicated that at least three polysulfides, i.e., $\mathrm{H}_{2} \mathrm{~S}_{2}, \mathrm{H}_{2} \mathrm{~S}_{3}$ and $\mathrm{H}_{2} \mathrm{~S}_{4}$, are produced in tissues [21]. Although various polysulfides could have different effects, this issue has not been widely examined until now. Second, $\mathrm{H}_{2} \mathrm{~S}$ and polysulfide production, and cyclic nucleotide concentrations were measured only in one adipose tissue depot. Although various parts of the adipose tissue differ significantly, the mesenteric adipose tissue used by us is a part of the visceral adipose tissue, which is highly lipolytically active and is involved in the pathogenesis of obesity-associated complications [1]. In addition, the effect of PKA and PKG inhibitors were consistent with cyclic nucleotide concentrations, suggesting that the adipose tissue depot used by us was representative regarding systemic regulation of lipolysis by reactive sulfur species. Third, we administered only a single dose of $\mathrm{Na}_{2} \mathrm{~S}$ or $\mathrm{Na}_{2} \mathrm{~S}_{4}$, whereas obesity is associated with long-term changes in $\mathrm{H}_{2} \mathrm{~S}$ / polysulfide levels. However, the interconversion of $\mathrm{H}_{2} \mathrm{~S}$ and $\mathrm{H}_{2} \mathrm{~S}_{n}$ due to redox reactions in vivo should be expected, and the single dose used by us may be more suitable to differentiate between the effects of these reactive sulfur species.

In conclusion, we demonstrated that not only $\mathrm{H}_{2} \mathrm{~S}$ but also polysulfides are produced by the adipose tissue. Both reactive sulfur species are produced by different enzymes, have various biological activities and are differentially regulated by obesity. In particular, $\mathrm{H}_{2} \mathrm{~S}$ stimulates lipolysis in a cAMP-PKA-dependent manner. Increased $\mathrm{H}_{2} \mathrm{~S}$ production in the adipose tissue can contribute to stimulation of lipolysis and, in the long run, may accelerate fatty acid-mediated complications such as insulin resistance.

\section{Materials and Methods}

\subsection{Animals and Reagents}

All experiments were performed in 84 adult (2- to 2.5-month-old) male Wistar rats weighing $200-230 \mathrm{~g}$. The study was approved by the Local Ethical Committee in Lublin (approval number 19/2019). Animals were kept at a temperature of $20 \pm 2{ }^{\circ} \mathrm{C}$ under a 12-h light-dark cycle and had free access to standard laboratory chow and tap water. Animals were anesthetized by ethylurethane $(1.25 \mathrm{~g} / \mathrm{kg}$ ip) A thin polyethylene cannula (World Precision Instruments, Sarasota, FL, USA) was inserted into the carotid vein for continuous infusion of physiological saline $(2 \mathrm{~mL} /$ hour $)$ to avoid hypovolemia. The second cannula was inserted into the carotid artery for blood sampling. Their temperature was monitored by a rectal thermometer (World Precision Instruments, Sarasota, FL, USA) and was maintained at $36.5-37.5^{\circ} \mathrm{C}$ using a heating table. Until otherwise stated, all reagents were obtained from Sigma-Aldrich (Steinheim, Germany). 


\subsection{Effect of $\mathrm{H}_{2} \mathrm{~S}$ and Polysulfide Donors on Plasma NEFA, Glycerol, Glucose and Insulin}

In the first set of experiments, we examined the effect of $\mathrm{H}_{2} \mathrm{~S}$ donor, $\mathrm{Na}_{2} \mathrm{~S}$, and the polysulfide donor, $\mathrm{Na}_{2} \mathrm{~S}_{4}$, on plasma NEFA, glycerol, glucose and insulin concentrations. After a 30-min stabilization period, the baseline blood sample was collected. Next, $0.5 \mathrm{~mL}$ of $0.9 \% \mathrm{NaCl}$ (control), $\mathrm{Na}_{2} \mathrm{~S}$ or $\mathrm{Na}_{2} \mathrm{~S}_{4}$ was administered intravenously (at $100 \mu \mathrm{mol} / \mathrm{kg}$ in $0.5 \mathrm{~mL} 0.9 \% \mathrm{NaCl})$. Blood samples $(0.5 \mathrm{~mL})$ were collected after 15, 30, 45 and $60 \mathrm{~min}$ into tubes containing EDTA and were centrifuged at $2000 \times g$ for $5 \mathrm{~min}$. Plasma was frozen and stored at $-80^{\circ} \mathrm{C}$ until the assay. Fifteen minutes after $\mathrm{NaCl}, \mathrm{Na}_{2} \mathrm{~S}$ or $\mathrm{Na}_{2} \mathrm{~S}_{4}$ injection, slices of mesenteric adipose tissue were collected for the measurement of cyclic nucleotides and phosphodiesterase activity.

In additional animals, a dose-response effect of $\mathrm{Na}_{2} \mathrm{~S}$ on NEFA and glycerol was studied after injecting various doses $(1,5,10,50,100$ or $200 \mu \mathrm{mol} / \mathrm{kg})$ of this donor. Blood samples were collected $15 \mathrm{~min}$ after injection.

\subsection{Effect of Cyclic Nucleotide-Dependent Protein Kinase Inhibitors on the Lipolytic Response to $\mathrm{Na}_{2} \mathrm{~S}$}

The experiment was performed in 6 groups of rats receiving $0.5 \mathrm{~mL} 0.9 \% \mathrm{NaCl}$, the protein kinase A inhibitor KT5720 $(1 \mu \mathrm{mol} / \mathrm{kg})$ or the protein kinase $\mathrm{G}$ inhibitor KT5823 $(1 \mu \mathrm{mol} / \mathrm{kg})$ intraperitoneally and then, after $15 \mathrm{~min}, 0.5 \mathrm{~mL} 0.9 \% \mathrm{NaCl}$ or $100 \mu \mathrm{mol} / \mathrm{kg}$ $\mathrm{Na}_{2} \mathrm{~S}$ intravenously. Blood samples for the measurement of NEFA and glycerol were collected $15 \mathrm{~min}$ after the second injection.

\subsection{Role of the Adrenergic System in the Regulation of Lipolysis by $\mathrm{Na}_{2} \mathrm{~S}$}

The experiments were performed in 4 groups of rats receiving: (1) $0.5 \mathrm{~mL} 0.9 \% \mathrm{NaCl}$ ip. and then, after $15 \mathrm{~min}$, the $\beta$-adrenergic antagonist propranolol $(1 \mathrm{mg} / \mathrm{kg}$ iv), (2) $0.5 \mathrm{~mL}$ $0.9 \% \mathrm{NaCl}$ ip and then, after $15 \mathrm{~min}$, the $\beta$-adrenergic agonist isoproterenol $(1 \mathrm{mg} / \mathrm{kg}$ iv), (3) propranolol (1 mg/kg iv) and, after $15 \mathrm{~min}$, isoproterenol (1 mg/kg iv), or (4) propranolol $(1 \mathrm{mg} / \mathrm{kg}$ iv $)$ and, after $15 \mathrm{~min}, \mathrm{Na}_{2} \mathrm{~S}(100 \mu \mathrm{mol} / \mathrm{kg}$ iv.). Blood samples for the measurement of NEFA and glycerol were obtained $15 \mathrm{~min}$ after the second injection.

\subsection{Effect of Obesity on $\mathrm{H}_{2} \mathrm{~S}$ and Polysulfide Production by Adipose Tissue}

The study was performed in two groups of rats. The control group received standard chow (Agropol, Motycz, Poland providing 68\% calories from carbohydrates $20 \%$ protein and $12 \%$ fat, whereas the second group received a high-calorie diet containing standard chow and a mixture of milk powder, sucrose, glucose and soybean powder (1:1:1:1) [42]. The composition of this diet (percentage of calories derived from carbohydrates, proteins and fat) is similar to that of normal chow, but the diet is highly palatable and increases food intake. The animals were fed with both diets for 1 month ad libitum. According to our previous studies [43], this protocol results in the development of obesity but there are still no significant metabolic abnormalities in animals fed the high-calorie diet. Animal were anesthetized, the abdominal cavity was opened, and blood samples were collected from the abdominal aorta for the measurement of insulin, glucose, lipids, NEFA and glycerol. Slices of mesenteric adipose tissue were collected for the measurement of $\mathrm{H}_{2} \mathrm{~S}$ and $\mathrm{H}_{2} \mathrm{~S}_{\mathrm{n}}$ production.

\subsection{Measurement of $\mathrm{H}_{2} \mathrm{~S}$ and Polysulfide Production by Adipose Tissue}

The generation of $\mathrm{H}_{2} \mathrm{~S}$ by adipose tissue explants was measured by a $\mathrm{H}_{2} \mathrm{~S}$-selective sensor (ISO-H2S-2; World Precision Instruments, Sarasota, FL, USA) connected to a Four-Channel Free Radical Analyzer (TBR-4100) and a Lab-Trax-4/24T data acquisition system (World Precision Instruments) according to the manufacturer's instructions. Each sensor was first calibrated by putting in the incubation solution without tissue and recording the current after adding increasing concentrations of $\mathrm{Na}_{2} \mathrm{~S}$. The calibration curve was constructed to calculate the sensor's sensitivity (increase in current per unit of sulfide concentration). 
After washing, slices of mesenteric adipose tissue (about $10 \mathrm{mg}$ ) were placed in 2-mL vials closed with tight caps containing a buffered Krebs-Ringer solution $(114 \mathrm{mM} \mathrm{NaCl}$, $5 \mathrm{mM} \mathrm{KCl}, 1.2 \mathrm{mM} \mathrm{KH}_{2} \mathrm{PO}_{4}, 1.2 \mathrm{mM} \mathrm{MgSO}_{4}, 1.0 \mathrm{mM} \mathrm{CaCl}_{2}, 17 \mathrm{mM} \mathrm{NaHCO}, 5.6 \mathrm{mM}$ glucose and $16 \mathrm{mM}$ Tris; $\mathrm{pH}$ 7.4) saturated with a mixture of $\mathrm{N}_{2}(90 \%), \mathrm{O}_{2}(5 \%)$ and $\mathrm{CO}_{2}(5 \%)$. According to previous studies, $\mathrm{H}_{2} \mathrm{~S}$ production is close to physiological at this $\mathrm{O}_{2}$ concentration [44]. The $\mathrm{H}_{2} \mathrm{~S}$ sensor and a thin needle (for application of tested substances) were mounted through the caps so that their ends remained $5 \mathrm{~mm}$ above the vial bottom. After a 5-min equilibration period, substrates and/or inhibitors of $\mathrm{H}_{2} \mathrm{~S}$ synthesizing enzymes were added, and the measurement was started. The increase in current over time between 1 and 5 min after the addition of $\mathrm{H}_{2} \mathrm{~S}$ donor was monitored, and the regression line (current $=a \times$ time $+b$ ) was fitted to the data by the least-squares method. $\mathrm{H}_{2} \mathrm{~S}$ production was calculated from the slope (" $a$ ") according to the sensitivity of the respective sensor. Each measurement was performed in two replications; in one of them, $1 \mathrm{mM}$ dithiotreitol (DTT) was added to the incubation medium to reduce polysulfides to $\mathrm{H}_{2} \mathrm{~S}$. The signal measured in the sample without DTT was considered to be $\mathrm{H}_{2} \mathrm{~S}$, whereas that measured in the sample with DTT was considered to be total $\mathrm{H}_{2} \mathrm{~S}+$ polysulfides. The amount of polysulfides produced was calculated as the difference between the samples containing and not containing DTT.

\subsection{Measurement of NEFA Concentrations}

Plasma non-esterified fatty acids were measured by the spectrofluorometric method using the kit provided by Cayman Chemical, Ann Arbor, MI, USA. In this method, fatty acids were first converted to acyl-CoA in the presence of Coenzyme A, ATP and acylCoA synthetase. Next, acyl-CoA is oxidized by acyl-CoA oxidase to 2,3-trans-enoiloCoA and $\mathrm{H}_{2} \mathrm{O}_{2}$. Then, $\mathrm{H}_{2} \mathrm{O}_{2}$ reacted with 10-acetyl-3,7-dihydroxyphenoxazine in the presence of horseradish peroxidase to form resorufin, which was measured at the excitation/emission wavelengths of 535/590 nm. Fluorescence was measured with a microplate reader (PHERAstar FS, BMG Labtech, Orttenberg, Germany). Before the assay, plasma samples were diluted 3-fold. The NEFA concentration was calculated from the standard curve (0-0.25 mM oleic acid). The sensitivity of the method was $12 \mu \mathrm{M}$, whereas the intraand inter-assay coefficients of variation were $2.6 \%$ and $3.9 \%$, respectively.

\subsection{Measurement of Glycerol Concentration}

Plasma glycerol was measured spectrophotometrically using the Cayman Chemical kit (Ann Arbor, MI, USA cat. \#10010755). Glycerol was first phosphorylated by glycerol kinase to glycerol-3-phosphate, which was then oxidized by glycerol-3-phosphate oxidase to dihydroxyacetone phosphate and $\mathrm{H}_{2} \mathrm{O}_{2} \cdot \mathrm{H}_{2} \mathrm{O}_{2}$ then reacted with aminoantipyrine and N-ethyl-N-(3-sulfopropyl)-m-anisidine, forming a chromogenic quinoneimine compound, the absorbance of which was measured at $540 \mathrm{~nm}$. The sensitivity of the method, and the intra- and inter-assay coefficients of variation were $13 \mu \mathrm{M}, 4.5 \%$ and $6.8 \%$, respectively.

\subsection{Measurement of Cyclic Nucleotides in the Adipose Tissue}

Adipose tissue slices were homogenized in $50 \mathrm{mM} \mathrm{NaCl}$ buffered with a phosphate buffer ( $\mathrm{pH}$ 7.4) containing $10 \mu \mathrm{M}$ of the phosphodiesterase inhibitor 3-isobutyl1-methylxanthine (IBMX) to inhibit cAMP and cGMP hydrolysis during sample processing $(100 \mu \mathrm{L}$ of buffer $/ 10 \mathrm{mg}$ tissue). The homogenate was centrifuged at $14000 \times g$ for $10 \mathrm{~min}$ at $4{ }^{\circ} \mathrm{C}$ and diluted 100-fold. Cyclic AMP and cyclic GMP concentrations were measured immunoenzymatically by Cayman Chemical kits (Ann Arbor, MI, USA cat.\# 581001 and 581121, respectively). The sensitivity, intra-assay CV and inter-assay CV values for cAMP and cGMP were $0.1 \mathrm{pmol} / \mathrm{mL}, 5.1 \%$ and $7.0 \%$, and $0.9 \mathrm{pmol} / \mathrm{mL}, 4.7 \%$ and $7.7 \%$, respectively. 


\subsection{Measurement of Phosphodiesterase (PDE) Activity in the Adipose Tissue}

cAMP-hydrolyzing PDE activity was measured using a kit purchased from BioVision (Milpitas, CA, USA, catalogue number K-2013-10). Ten mg of adipose tissue was homogenized in $100 \mu \mathrm{L}$ of a buffer containing in the kit and centrifuged at $1000 \times g$ for $15 \mathrm{~min}$ at $4{ }^{\circ} \mathrm{C}$. The supernatant $(20 \mu \mathrm{L})$ was transferred to microplate wells and was diluted with $30 \mu \mathrm{L}$ of a phosphate buffer. Each sample was measured in 2 replications; one of them contained $2 \mu \mathrm{L}$ of a cAMP solution. The product (AMP) was converted to a fluorescent compound by the mixture of enzymes and reagents provided with the kit. Fluorescence was measured at the excitation and emission wavelengths of $535 \mathrm{~nm}$ and $587 \mathrm{~nm}$, respectively, in the kinetic mode for $30 \mathrm{~min}$. AMP concentration was calculated from the standard curve (0-1000 pmol AMP/well). The increase in fluorescence between 5 and $15 \mathrm{~min}$ in the sample that did not contain cAMP was subtracted from the increase in fluorescence in the sample containing cAMP. Enzyme activity was expressed in $\mathrm{pmol} \mathrm{AMP} / \mathrm{min}$ per $\mathrm{mg}$ protein.

\subsection{Measurement of Glucose, Lipids and Insulin}

Plasma glucose, triglycerides and total cholesterol were measured with kits purchased from Alfa Diagnostics (Warsaw, Poland). Plasma insulin was measured immunoenzymatically using the Mercodia kit (cat. \#10-1250-01). The sensitivity, intra-assay and inter-assay $\mathrm{CV}$ values for insulin measurement were $0.15 \mu \mathrm{g} / \mathrm{L}, 3.1 \%$ and $4.4 \%$, respectively. The anti-insulin antibodies contained in the kit exhibited $7 \%$ cross-reactivity with rat proinsulin and $0.001 \%$ cross-reactivity with rat $C$ peptide.

\subsection{Statistical Analysis}

The results are expressed as the means \pm SD of 6 animals/adipose tissue samples per group. Between-group comparisons were performed by Student's t-test or ANOVA, followed by Tukey's test for 2 groups and $>2$ groups, respectively. The results from the same group obtained at different time points were analyzed by ANOVA for related variables. The area under the curve (AUC) of plasma NEFA and glycerol concentrations was calculated by the trapezoidal method, taking the baseline concentration in the control group as 0 . A $p<0.05$ was considered statistically significant.

Author Contributions: Conceptualization, J.B.; methodology, J.B.; investigation, J.B. and K.W.; writing—original draft preparation, K.W.; writing—review and editing, J.B.; visualization, K.W.; funding acquisition, J.B. All authors have read and agreed to the published version of the manuscript.

Funding: This research was funded by Medical University of Lublin (grant number DS476).

Institutional Review Board Statement: The study protocol was approved by the Local Ethics Committee in Lublin (approval number 19/2019).

Data Availability Statement: Original data are available from the corresponding author on request.

Conflicts of Interest: The authors declare no conflict of interest. The funding institution had no role in the design of the study; in the collection, analyses, or interpretation of data; in the writing of the manuscript; or in the decision to publish the results.

\section{References}

1. Tchernof, A.; Després, J.P. Pathophysiology of human visceral obesity: An update. Physiol. Rev. 2013, 93, 359-404. [CrossRef] [PubMed]

2. Chait, A.; den Hartigh, L.J. Adipose tissue distribution, inflammation and its metabolic consequences, including diabetes and cardiovascular disease. Front. Cardiovasc. Med. 2020, 7, 22. [CrossRef] [PubMed]

3. Recinella, L.; Orlando, G.; Ferrante, C.; Chiavaroli, A.; Brunetti, L.; Leone, S. Adipokines: New potential therapeutic target for obesity and metabolic, rheumatic, and cardiovascular diseases. Front. Physiol. 2020, 11, 578966. [CrossRef] [PubMed]

4. La Russa, D.; Marrone, A.; Mandalà, M.; Macirella, R.; Pellegrino, D. Antioxidant/anti-inflammatory effects of caloric restriction in an aged and obese rat Model: The role of adiponectin. Biomedicines 2020, 8, 532. [CrossRef]

5. Stanek, A.; Brożyna-Tkaczyk, K.; Myśliński, W. The role of obesity-induced perivascular adipose tissue (PVAT) dysfunction in vascular homeostasis. Nutrients 2021, 13, 3843. [CrossRef] 
6. Hu, H.; Garcia-Barrio, M.; Jiang, Z.S.; Chen, Y.E.; Chang, L. Roles of perivascular adipose tissue in hypertension and atherosclerosis. Antioxid. Redox Signal. 2021, 34, 736-749. [CrossRef]

7. Wang, Z.; Wang, Q.A.; Liu, Y.; Jiang, L. Energy metabolism in brown adipose tissue. FEBS J. 2021, 288, 3647-3662. [CrossRef]

8. Singh, R.; Barrios, A.; Dirakvand, G.; Pervin, S. Human brown adipose tissue and metabolic health: Potential for therapeutic avenues. Cells 2021, 10, 3030. [CrossRef]

9. Blüher, M. Obesity: Global epidemiology and pathogenesis. Nat. Rev. Endocrinol. 2019, 15, 288-298. [CrossRef]

10. La Russa, D.; Giordano, F.; Marrone, A.; Parafati, M.; Janda, E.; Pellegrino, D. Oxidative imbalance and kidney damage in cafeteria diet-induced rat model of metabolic syndrome: Effect of Bergamot polyphenolic fraction. Antioxidants 2019, 8, 66. [CrossRef]

11. Bolsoni-Lopes, A.; Alonso-Vale, M.I. Lipolysis and lipases in white adipose tissue-An update. Arch. Endocrinol. Metab. 2015, 59, 335-342. [CrossRef]

12. Frühbeck, G.; Méndez-Giménez, L.; Fernández-Formoso, J.A.; Fernández, S.; Rodríguez, A. Regulation of adipocyte lipolysis Nutr. Res. Rev. 2014, 27, 63-93. [CrossRef] [PubMed]

13. Arner, P.; Langin, D. Lipolysis in lipid turnover, cancer cachexia, and obesity-induced insulin resistance. Trends Endocrinol. Metab. 2014, 25, 255-262. [CrossRef] [PubMed]

14. Nielsen, T.S.; Jessen, N.; Jørgensen, J.O.; Møller, N.; Lund, S. Dissecting adipose tissue lipolysis: Molecular regulation and implications for metabolic disease. J. Mol. Endocrinol. 2014, 52, R199-R222. [CrossRef] [PubMed]

15. Bełtowski, J.; Jamroz-Wiśniewska, A. Hydrogen sulfide in the adipose tissue-physiology, pathology and a target for pharmacotherapy. Molecules 2016, 22, 63. [CrossRef]

16. Fang, L.; Zhao, J.; Chen, Y.; Ma, T.; Xu, G.; Tang, C.; Liu, X.; Geng, B. Hydrogen sulfide derived from periadventitial adipose tissue is a vasodilator. J. Hypertens. 2009, 27, 2174-2185. [CrossRef]

17. Cai, J.; Shi, X.; Wang, H.; Fan, J.; Feng, Y.; Lin, X.; Yang, J.; Cui, Q.; Tang, C.; Xu, G.; et al. Cystathionine $\gamma$ lyase-hydrogen sulfide increases peroxisome proliferator-activated receptor $\gamma$ activity by sulfhydration at $\mathrm{C} 139$ site thereby promoting glucose uptake and lipid storage in adipocytes. Biochim. Biophys. Acta 2016, 1861, 419-429. [CrossRef]

18. Feng, X.; Chen, Y.; Zhao, J.; Tang, C.; Jiang, Z.; Geng, B. Hydrogen sulfide from adipose tissue is a novel insulin resistance regulator. Biochem. Biophys. Res. Commun. 2009, 380, 153-169. [CrossRef]

19. Huang, C.Y.; Yao, W.F.; Wu, W.G.; Lu, Y.L.; Wan, H.; Wang, W. Endogenous CSE/H2 S system mediates TNF- $\alpha$-induced insulin resistance in 3T3-L1 adipocytes. Cell Biochem. Funct. 2013, 31, 468-475. [CrossRef]

20. Velmurugan, G.V.; Huang, H.; Sun, H.; Candela, J.; Jaiswal, M.K.; Beaman, K.D.; Yamashita, M.; Prakriya, M.; White, C. Depletion of $\mathrm{H}_{2} \mathrm{~S}$ during obesity enhances store-operated $\mathrm{Ca}^{2+}$ entry in adipose tissue macrophages to increase cytokine production. Sci. Signal. 2015, 8, ra128. [CrossRef]

21. Kimura, $\mathrm{H}$. Hydrogen sulfide $\left(\mathrm{H}_{2} \mathrm{~S}\right)$ and polysulfide $\left(\mathrm{H}_{2} \mathrm{~S}_{\mathrm{n}}\right)$ signaling: The first 25 years. Biomolecules 2021, 11, 896. [CrossRef] [PubMed]

22. Sawa, T.; Motohashi, H.; Ihara, H.; Akaike, T. Enzymatic regulation and biological functions of reactive cysteine persulfides and polysulfides. Biomolecules 2020, 10, 1245. [CrossRef] [PubMed]

23. Liu, H.; Radford, M.N.; Yang, C.T.; Chen, W.; Xian, M. Inorganic hydrogen polysulfides: Chemistry, chemical biology and detection. Br. J. Pharmacol. 2019, 176, 616-627. [CrossRef] [PubMed]

24. Yang, G.; Ju, Y.; Fu, M.; Zhang, Y.; Pei, Y.; Racine, M.; Baath, S.; Merritt, T.J.S.; Wang, R.; Wu, L. Cystathionine gammalyase/hydrogen sulfide system is essential for adipogenesis and fat mass accumulation in mice. Biochim. Biophys. Acta Mol. Cell Biol. Lipids 2018, 1863, 165-176. [CrossRef]

25. Nagahara, N.; Koike, S.; Nirasawa, T.; Kimura, H.; Ogasawara, Y. Alternative pathway of $\mathrm{H}_{2} \mathrm{~S}$ and polysulfides production from sulfurated catalytic-cysteine of reaction intermediates of 3-mercaptopyruvate sulfurtransferase. Biochem. Biophys. Res. Commun. 2018, 496, 648-653. [CrossRef]

26. Geng, B.; Cai, B.; Liao, F.; Zheng, Y.; Zeng, Q.; Fan, X.; Gong, Y.; Yang, J.; Cui, Q.H.; Tang, C.; et al. Increase or decrease hydrogen sulfide exert opposite lipolysis, but reduce global insulin resistance in high fatty diet induced obese mice. PLoS ONE 2013, 8, e73892. [CrossRef]

27. Ding, Y.; Wang, H.; Geng, B.; Xu, G. Sulfhydration of perilipin 1 is involved in the inhibitory effects of cystathionine gamma lyase/hydrogen sulfide on adipocyte lipolysis. Biochem. Biophys. Res. Commun. 2020, 521, 786-790. [CrossRef]

28. Hughes, M.N.; Centelles, M.N.; Moore, K.P. Making and working with hydrogen sulfide: The chemistry and generation of hydrogen sulfide in vitro and its measurement in vivo: A review. Free Radic. Biol. Med. 2009, 47, 1346-1353. [CrossRef]

29. Ciccone, V.; Genah, S.; Morbidelli, L. Endothelium as a source and target of $\mathrm{H}_{2} \mathrm{~S}$ to improve its trophism and function. Antioxidants 2021, 10, 486. [CrossRef]

30. Abramavicius, S.; Petersen, A.G.; Renaltan, N.S.; Prat-Duran, J.; Torregrossa, R.; Stankevicius, E.; Whiteman, M.; Simonsen, U. GYY4137 and sodium hydrogen sulfide relaxations are inhibited by L-Cysteine and $\mathrm{K}_{\mathrm{V}} 7$ channel blockers in rat small mesenteric arteries. Front. Pharmacol. 2021, 12, 613989. [CrossRef]

31. Grambow, E.; Mueller-Graf, F.; Delyagina, E.; Frank, M.; Kuhla, A.; Vollmar, B. Effect of the hydrogen sulfide donor GYY4137 on platelet activation and microvascular thrombus formation in mice. Platelets 2014, 25, 166-174. [CrossRef] [PubMed]

32. Bazhanov, N.; Escaffre, O.; Freiberg, A.N.; Garofalo, R.P.; Casola, A. Broad-range antiviral activity of hydrogen sulfide against highly pathogenic RNA viruses. Sci. Rep. 2017, 7, 41029. [CrossRef] [PubMed] 
33. Drapala, A.; Koszelewski, D.; Tomasova, L.; Ostaszewski, R.; Grman, M.; Ondrias, K.; Ufnal, M. Parenteral Na 2 S, a fast-releasing $\mathrm{H}_{2} \mathrm{~S}$ donor, but not GYY4137, a slow-releasing $\mathrm{H}_{2} \mathrm{~S}$ donor, lowers blood pressure in rats. Acta Biochim. Pol. 2017, 64, 561-566. [CrossRef] [PubMed]

34. Nam, H.; Jung, H.; Kim, Y.; Kim, B.; Kim, K.H.; Park, S.J.; Suh, J.G. Aged black garlic extract regulates lipid metabolism by inhibiting lipogenesis and promoting lipolysis in mature 3T3-L1 adipocytes. Food Sci. Biotechnol. 2017, 27, 575-579. [CrossRef] [PubMed]

35. Ceddia, R.P.; Collins, S. A compendium of G-protein-coupled receptors and cyclic nucleotide regulation of adipose tissue metabolism and energy expenditure. Clin. Sci. 2020, 134, 473-512. [CrossRef] [PubMed]

36. Cao, X.; Wu, Z.; Xiong, S.; Cao, L.; Sethi, G.; Bian, J.S. The role of hydrogen sulfide in cyclic nucleotide signaling. Biochem. Pharmacol. 2018, 149, 20-28. [CrossRef]

37. Katsouda, A.; Szabo, C.; Papapetropoulos, A. Reduced adipose tissue $\mathrm{H}_{2} \mathrm{~S}$ in obesity. Pharmacol. Res. 2018, 128, 190-199. [CrossRef]

38. Comas, F.; Latorre, J.; Ortega, F.; Arnoriaga Rodríguez, M.; Kern, M.; Lluch, A.; Ricart, W.; Blüher, M.; Gotor, C.; Romero, L.C.; et al. Activation of endogenous $\mathrm{H}_{2} \mathrm{~S}$ biosynthesis or supplementation with exogenous $\mathrm{H}_{2} \mathrm{~S}$ enhances adipose tissue adipogenesis and preserves adipocyte physiology in humans. Antioxid. Redox Signal. 2021, 35, 319-340. [CrossRef]

39. Alkhouri, N.; Eng, K.; Cikach, F.; Patel, N.; Yan, C.; Brindle, A.; Rome, E.; Hanouneh, I.; Grove, D.; Lopez, R.; et al. Breathprints of childhood obesity: Changes in volatile organic compounds in obese children compared with lean controls. Pediatr. Obes. 2015, 10, 23-29. [CrossRef]

40. Comas, F.; Latorre, J.; Ortega, F.; Arnoriaga Rodríguez, M.; Lluch, A.; Sabater, M.; Rius, F.; Ribas, X.; Costas, M.; Ricart, W.; et al. Morbidly obese subjects show increased serum sulfide in proportion to fat mass. Int. J. Obes. 2021, 45, 415-426. [CrossRef]

41. Whiteman, M.; Gooding, K.M.; Whatmore, J.L.; Ball, C.I.; Mawson, D.; Skinner, K.; Tooke, J.E.; Shore, A.C. Adiposity is a major determinant of plasma levels of the novel vasodilator hydrogen sulphide. Diabetologia 2010, 53, 1722-1726. [CrossRef]

42. Pedersen, O.; Kahn, C.R.; Flier, J.S.; Kahn, B.B. High fat feeding causes insulin resistance and a marked decrease in the expression of glucose transporters (Glut 4) in fat cells of rats. Endocrinology 1991, 129, 771-777. [CrossRef] [PubMed]

43. Bełtowski, J.; Wójcicka, G.; Jamroz-Wiśniewska, A.; Marciniak, A. Resistance to acute NO-mimetic and EDHF-mimetic effects of leptin in the metabolic syndrome. Life Sci. 2009, 85, 557-567. [CrossRef] [PubMed]

44. Bełtowski, J.; Guranowski, A.; Jamroz-Wiśniewska, A.; Wolski, A.; Hałas, K. Hydrogen-sulfide-mediated vasodilatory effect of nucleoside 5'-monophosphorothioates in perivascular adipose tissue. Can. J. Physiol. Pharmacol. 2015, 93, 585-595. [CrossRef] [PubMed] 